\title{
Deprivation of Citizenship: Is There an Issue of EU Law?
}

\author{
Jo Shaw
}

The purpose of this short intervention in the debate on The Return of Banishment initiated by Audrey Macklin, where the pros and cons of various forms of deprivation policies pursued by, or sought by, liberal states have been fully debated, is to add an element of EU law. Specifically, in the light of the judgments of the European Court of Justice in Rottmann ${ }^{1}$ and Ruiz Zambrano ${ }^{2}$, how - if at all - are Member States' laws and procedures on involuntary loss of citizenship affected by EU law, given that the primary competence to determine the rules on the acquisition and loss of citizenship remains with Member States? At the time of the hearing, well informed observers $^{3}$ who followed the UK Supreme Court hearing in the case of $B 2$ (Pham) v SSHD 4 concerned with the UK's rather extensive deprivation powers and the issue of statelessness indicated that they thought it likely that the Supreme Court would make a reference to the Court of Justice. It seemed that the judges would ask the CJEU if it really meant what it said when it decided the case of Rottmann. B2 (Pham), like the earlier cases of G1 (discussed below) and as well as the case of ${ }^{5}$, a former Iraqi citizen who has

\footnotetext{
C-135/08, available at http://curia.europa.eu/juris/liste.jsf?num=C-135/08

C-34/09, available at http://curia.europa.eu/juris/liste.

jsf?language $=$ en\&num $=\mathrm{C}-34 / 09$

3 Cox, S. (2014), 'Rottmann Rules UK? Can British citizenship be taken away
} without regard to EU law?', EU Law Analysis, available at http://eulawanalysis.blogspot.com.es/2014/11/rottmann-rules-uk-can-british.html; Woodrow, P. (2014), 'Statelessness, deprivation of nationality, and EU Citizenship... what is B2 in the Supreme Court really all about?', freemovement, available at https:// www.freemovement.org.uk/statelessness-deprivation-of-nationality-and-eucitizenshipwhat-is-b2-in-the-supreme-court-really-all-about/. In the event, no reference was made [comment added in June 2018 to text prepared in 2014].

4 Pham (Appellant) v Secretary of State for the Home Department (Respondent) [2015] UKSC 19, available at https://www.supremecourt.uk/cases/uksc-20130150.html

5 Secretary of State for the Home Department v Al-Jedda [2013] UKSC 62 (9 October 2013), available at http://www.bailii.org/uk/cases/UKSC/2013/62.html 
twice been stripped of his UK citizenship as well as spending time in military detention in $\mathrm{Iraq}^{6}$, all concern naturalised citizens who are suspected of some form of terrorist involvement, but against none of whom criminal proceedings have been brought in the UK.

We are likely, therefore, to be in a phase of further legal development initially in iteration between the UK courts and the Court of Justice, but with implications for all of the Member States as quite a number of states have started to look closely at using expatriation measures in order to combat radicalisation and terrorist threats, even if many judge this approach to be ill-advised and inappropriate.

I will explain briefly what the issues are. The Rottmann case was the subject of an earlier Forum Debate ${ }^{7}$ on the EUDO Citizenship website. Rottmann was a case of loss of citizenship conferred by naturalisation, after it came to light that the naturalisation had been obtained by fraud. In this case, Rottmann, an Austrian citizen, had failed to reveal that he had been the subject of unconcluded criminal proceedings in Austria when seeking naturalisation in Germany. Rottmann raised issues of EU law in his appeal against the deprivation decision before the German administrative courts, which led to a reference to the Court of Justice. He pointed out that having obtained German citizenship he lost Austrian citizenship, by operation of law. Thus, if he were deprived of German citizenship he would be stateless, and - furthermore - he would have lost his EU citizenship. One issue that had been raised - and which caught the attention of Advocate General Maduro in his Opinion - was whether this was a 'wholly internal situation' i.e. a German court reviewing a decision of a German public authority regarding a German citizen. In that sense, it could be said, EU citizenship was not engaged at all. In response, the Court repeated its standard formulation when dealing with matters which fall outside the competence of the EU and its legislature. It reminded us that EU cannot adopt measures with regard to national citizenship, but none the less while national competence remains intact, it must be exercised 'with due regard' to the requirements of EU law in situations covered by EU law. Specifically, in this case, said the Court:

6 'Al-Jedda, "statelessness" and the meaning of words', Freemovement, 25 October 2013, available at https://www.freemovement.org.uk/ al-jedda-statelessness-and-the-meaning-of-words/

7 Shaw, J. (2011), 'Has the European Court of Justice Challenged Member State Sovereignty in Nationality Law?', Robert Schuman Centre for Advanced Studies, EUDO Citizenship Observatory Working Paper No. 2011/62, Florence: European University Institute, available at http://cadmus.eui.eu/ handle/1814/19654 
It is clear that the situation of a citizen of the Union who, like the applicant in the main proceedings, is faced with a decision withdrawing his naturalisation, adopted by the authorities of one Member State, and placing him, after he has lost the nationality of another Member State that he originally possessed, in a position capable of causing him to lose the status conferred by Article 17 EC [i.e. Union citizenship] and the rights attaching thereto falls, by reason of its nature and its consequences, within the ambit of European Union law (para. 42 of the judgment).

The Court went on to recognise that states may have legitimate reasons to withdraw citizenship, but it is worth noting that the Court of Justice does not, in this paragraph, focus on statelessness, but rather on the loss of the rights specific to EU law. In other words, this can be seen as an EU-specific reason for requiring the testing of any decision to withdraw citizenship against - as the Court went on to hold - a standard of proportionality. Factors to be borne in mind in assessing the proportionality of the withdrawal decision included the gravity of the original offence or deception, lapse of time, the impact on the subject of the decision and their family, the possibility of recovering the original citizenship lost at the time of naturalisation, and the availability of other less severe measures than withdrawal.

While some have suggested that the essence of Rottmann lay in the way that the claimant is strung across between the national citizenship laws of two EU Member States, one at least of which claims exclusivity and thus operates an automatic rule of withdrawal in the event that a citizen acquires the citizenship of another state, the point about loss of the benefits of EU citizenship as a freestanding principle of EU law without regard to prior movement from one Member State to another was given a further boost in the case of Ruiz Zambrano. In that case, the EU citizens threatened with losing their rights of citizenship were the children of the claimant, who were born in Belgium and who had acquired Belgian, and thus EU, citizenship at birth. Meanwhile, through a combination of circumstances their Colombian citizen father had not regularised his situation in Belgium (or had perhaps been prevented from doing so by a series of delays perpetrated by the Belgian authorities in relation to his case). Because the refusal of a residence permit for Ruiz Zambrano and his wife would, in effect, have meant that the EU citizen children would have been obliged to leave, with their parents, the territory of the EU and thus would not have been able to avail themselves of their rights as EU citizens (notably the right of free movement which they had not yet exercised, but which they might exercise in the future), the Court concluded that a Member State could not refuse to grant either a residence permit or indeed a work permit. The test that the Court articulated was 
whether the measure taken in relation to a third country national upon whom the EU citizen children were dependent was whether it would make them unable to exercise 'the substance of their rights' as citizens of the EU.

Neither Rottmann nor - in particular - Ruiz Zambrano have been met with unalloyed enthusiasm at the national level. It goes beyond the scope of this short comment to discuss how and why Member States and indeed their courts might react to challenging judgments of the Court of Justice that appear to extend the scope of EU law and, in particular, the scope of EU citizenship. ${ }^{8}$ That said, there is no evidence to suggest that, thus far, Rottmann has had a significant or disruptive effect on national citizenship laws. ${ }^{9}$

The UK is one of the few states where Rottmann has thus far been discussed in national cases, but - until the case of B2 (Pham) which is before the Supreme Court - the limit of consideration had been a rather dismissive swipe at the Court of Justice taken by Lord Justice Laws in the Court of Appeal in the case of $G 1 \mathrm{v} S S H D^{10}$. Laws LJ sceptically asked '[u]pon what principled basis, therefore, should the grant or withdrawal of State citizenship be qualified by an obligation to "have due regard" to the law of the European Union?' (para. 38), given that the grant and withdrawal of citizenship remains a matter of Member State competence.

The Supreme Court refused to give leave to appeal to the applicant in G1, but perhaps it was only a matter of time, given the salience of deprivation of citizenship in the UK at the present time, before it had to grasp the nettle of considering not only the meaning of statelessness in the context of the then applicable UK law (this having moved on somewhat since that time, as Gibney's contribution to the Forum highlights) but also the possible applicability of EU law as a restraint upon executive freedom, and as a standard

8 Blauberger, M. (2012), 'With Luxembourg in mind ... the remaking of national policies in the face of ECJ jurisprudence', Journal of European Public Policy 19 (1): 109-126; Blauberger, M. (2014), 'National Responses to European Court Jurisprudence', West European Politics 37 (3): 457-474; Schmidt, S. (2014), 'Judicial Europeanisation: The Case of Zambrano in Ireland', West European Politics 37 (4): 769-785.

9 See Shuibhne, N. N. \& J. Shaw (2014), 'General Report General Report: Union Citizenship: Development, Impact and Challenges', in U. Neergaard, C. Jacqueson \& N. Holst-Christensen (eds.), Union Citizenship: Development, Impact and Challenges. The XXVI FIDE Congress in Copenhagen, Congress Publications Vol. 2, Copenhagen: DJØF Publishing. at p. 154-155.

10 G1 v Secretary of State [2012] EWCA Civ 867. Available at http://www.bailii. org/ew/cases/EWCA/Civ/2012/867.html 
which UK courts, in exercising their review function, would need to uphold. Hence the appellant in $B 2$ has been given leave to appeal, with perhaps a reference to the Court of Justice still to come.

As the discussion by Simon $\operatorname{Cox}^{11}$, a lawyer working with the Open Society Institute which intervened in this case ${ }^{12}$, has made clear, it seems quite likely that if the applicability of EU law as a frame of reference against which UK deprivation legislation needs to be judged is duly established by the Court of Justice and accepted by the Supreme Court, then the proportionality standards which need to be applied by UK courts exercising their review function may differ from those otherwise applicable within UK public law. The key issue seems likely to surround the putative autonomy of EU citizenship: is there a freestanding EU law related concern with citizenship stripping, namely the loss of EU citizenship rights, which goes beyond the issue of statelessness? Rottmann seemed to suggest there was, but this is the issue on which the Supreme Court may probe the CJEU further. It should be noted that there may also be higher standards of disclosure of otherwise secret evidence, following the judgment of the Court of Justice in the $Z Z$ case $^{13}$, if the applicability of EU law is accepted.

Finally, it should be pointed out that the OSI interest in the case is not directly with the Rottmann point, but concerns the definition of statelessness, which, they argue also has an EU element and should have a common EU level definition to which Member States are obliged to adhere. This call stems from the fear that in its earlier judgment in $B 2$ (Pham) the Court of Appea $1{ }^{14}$ created significant difficulties when it resolved that B2 was not to be judged as de jure stateless, once deprived of UK citizenship, because although the Vietnamese government indicated they did not recognise him as a citizen, it was clear that this was unlawful under Vietnamese law.

The UK courts, said the Court of Appeal, were bound by the rule of law. Therefore, they could not recognise an unlawful act of the Vietnamese government. This seems to be peculiarly Kafka-esque reasoning and the OSI, given its investment in the campaign against statelessness on-going under

11 Cited above n. 3.

12 Case No. UKSC 2013/0150, available at http://www.opensocietyfoundations. org/sites/default/files/b2-v-home-secretary-case-intervener-20 141105_0.pdf

13 C-300/11, available at http://curia.europa.eu/juris/liste.jsf?num=C-300/11

14 B2 v Secretary of State for the Home Department [2013] EWCA Civ 616 (24 May 2013), available at http://www.bailii.org/ew/cases/EWCA/Civ/2013/616. html 
the leadership of the UNHCR, would be concerned if this reasoning were to take hold in the UK, which is bound to have further cases coming before the courts, given the remarkable rate ${ }^{15}$ at which the state is now expatriating its citizens on grounds that this is conducive to the public good.

Open Access This chapter is licensed under the terms of the Creative Commons Attribution 4.0 International License (http://creativecommons.org/licenses/by/4.0/), which permits use, sharing, adaptation, distribution and reproduction in any medium or format, as long as you give appropriate credit to the original author(s) and the source, provide a link to the Creative Commons license and indicate if changes were made.

The images or other third party material in this chapter are included in the chapter's Creative Commons license, unless indicated otherwise in a credit line to the material. If material is not included in the chapter's Creative Commons license and your intended use is not permitted by statutory regulation or exceeds the permitted use, you will need to obtain permission directly from the copyright holder.

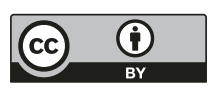

15 'Government release number of deprived of British citizenship since 2013', The Bureau of Investigative Journalism, 19 December 2014, available at https://www.thebureauinvestigates.com/stories/2014-12-19/ government-release-number-deprived-of-british-citizenship-since-2013 